\title{
Prevalence of occult hepatitis B infection in a highly endemic area for chronic hepatitis B: a study of a large blood donor population
}

\author{
Man-Fung Yuen, ${ }^{1}$ Cheuk-Kwong Lee, ${ }^{2}$ Danny Ka-Ho Wong, ${ }^{1}$ James Fung, ${ }^{1}$ \\ Ivan Hung, ${ }^{1}$ Axel Hsu, ${ }^{1}$ David Yiu-Kuen But, ${ }^{1}$ Ting-Kin Cheung, ${ }^{1}$ Pierre Chan, ${ }^{1}$ \\ John Chi-Hang Yuen, ${ }^{1}$ Frederic Khe-Cheong Fung, ${ }^{1}$ Wai-Kay Seto, ${ }^{1}$ Che-Kit Lin, ${ }^{2}$ \\ Ching-Lung Lai ${ }^{1}$
}

'Department of Medicine, The University of Hong Kong, Queen Mary Hospital, Hong Kong ${ }^{2}$ Hong Kong Red Cross Blood Transfusion Service, Hospital Authority, Hong Kong

\section{Correspondence to}

Professor Ching-Lung Lai, Department of Medicine, The University of Hong Kong, Queen Mary Hospital, Pokfulam Road, Hong Kong;

hrmelcl@hkucc.hku.hk

Revised 8 April 2010 Accepted 27 April 2010 Published Online First 30 July 2010

\section{ABSTRACT}

Background and aims The aim of the present study was to determine the population prevalence of occult hepatitis $B(\mathrm{OHB})$ infection and its clinical profile in a highly endemic area of chronic hepatitis B virus disease.

Methods OHB was first identified by individual sample testing for hepatitis B surface antigen (HBsAg) followed by nucleic acid testing (NAT) and vice versa for 3044 (cohort 1, stored sera from donation within 1 year) and 9990 (cohort 2, prospective study) blood donors,

respectively. OHB was confirmed meticulously by $\geq 2$ out of 3 tests with detectable hepatitis B virus (HBV) DNA using a sensitive standardised assay. Detailed serology and viral load in the serum and liver were studied. Results The prevalence of OHB was $0.13 \%$ (4/3044) and $0.11 \%(11 / 9967)$ for cohort 1 and 2, respectively. In cohort 2, 10 out of 11 OHB samples were positive for anti-HBc (hepatitis B core antigen) antibody (all were immunoglobulin G). Seven had detectable anti-HBs. The serum HBV DNA levels were extremely low (highest $14.1 \mathrm{IU} / \mathrm{ml})$. Of the six donors who underwent liver biopsies, all had normal liver biochemistry, extremely low liver HBV DNA (highest 6.21 copies/cell) and nearly normal liver histology. For those with viral sequence generation, none had the common HBsAg mutant G145R. Conclusions The prevalence of $\mathrm{OHB}$ in a highly endemic area of chronic HBV was very low, thus implying a low impact on transfusion services. To implement universal screening, the high cost of NAT should be taken into account. OHB blood donors had very low HBV replication, and normal liver biochemistry and histology, conferring a favourable prognosis.

\section{INTRODUCTION}

The prevalence of chronic hepatitis $\mathrm{B}(\mathrm{CHB})$ which affects 400 million people worldwide has been fully documented. ${ }^{1}$ The highly endemic regions with carrier rates of $>8 \%$ include Asia and Africa. However, there is a lack of systematic and population studies in Asia on the prevalence of occult hepatitis $\mathrm{B}(\mathrm{OHB})$ virus infection, defined as the presence of hepatitis B virus (HBV) DNA in the sera or livers in subjects who are negative for serum hepatitis B surface antigen (HBsAg). The paucity of population-based data on $\mathrm{OHB}$ may be due to two main reasons. First, the entity $\mathrm{OHB}$ has gained global attention only recently. Secondly, there is no

\section{Significance of this study}

What is already known about this subject?

- Occult hepatitis $B$, because of its low HBV DNA levels, is a notoriously difficult disease to study.

- Prevalence of occult hepatitis B varies greatly among different countries.

- The accuracy of detection of occult hepatitis B depends on the performance of tests.

- Occult hepatitis B blood donors may transmit hepatitis $B$ virus through blood transfusion.

\section{What are the new findings?}

- Even in a highly endemic area of chronic hepatitis $B$, the prevalence of occult hepatitis $B$ is low.

- Screening for occult hepatitis B by $\mathrm{HBsAg}$ testing followed by nucleic acid testing has the same yield compared with first screening by nucleic acid testing.

- Serum and liver HBV DNA levels in subjects with occult hepatitis B are extremely low and highly sensitive assays are required to diagnose the disease.

- Subjects with occult hepatitis B have normal liver biochemistries and liver histology.

\section{How might it impact on clinical practice in the foreseeable future?}

- The finding of low prevalence of occult hepatitis $B$ in a highly endemic area of chronic hepatitis $B$ provides useful information for planning and implementation of screening of this disease in transfusion services.

- The finding of the present study provides evidence that screening by $\mathrm{HBsAg}$ testing followed by nucleic acid testing may be the more cost-effective approach.

- Subjects with occult hepatitis B, because of the low viral levels and nearly normal liver histology, are expected to have a good long-term outcome.

generally accepted assay of HBV DNA detection for $\mathrm{OHB}$ in which serum HBV DNA levels are usually extremely low $(<200 \mathrm{IU} / \mathrm{ml}) .^{2}{ }^{3}$ However, studies on the prevalence of $\mathrm{OHB}$ have many implications for the blood transfusion services as the infectivity of blood products from donors with $\mathrm{OHB}$ remains 
largely unknown. The prevalence documented in cohort studies is usually $<1 \%{ }^{4-7}$ Large population studies are required in order to define the prevalence with higher confidence of accuracy.

In addition, the serology, virology (in serum and in the liver) and histology of subjects with incidental identification of $\mathrm{OHB}$ have not been studied in detail.

We carried out the present large population study in Hong Kong (where $8 \%$ of the population has $\mathrm{CHB}$ ) with the primary aim of determining the prevalence of $\mathrm{OHB}$ in our general population by using two different screening strategies. The secondary aims were to examine the viral and disease status of subjects with $\mathrm{OHB}$.

\section{PATIENTS AND METHODS}

The present study was carried out in two stages with two cohorts. The first stage (cohort 1) involved testing of 3044 stored sera randomly selected by the Hong Kong Red Cross Transfusion Service. These sera were from blood donors who donated blood within 1 year of the start of the present study. The time of donation of these samples was between 1 June 2005 and 31 May 2006. The samples were retrieved from all the 18 governorates of Hong Kong. All donor sera were first tested negative for HBsAg (Abbott PRISM, Abbott Laboratories, Abbott Park, Illinois, USA), antibody to hepatitis C virus (HCV) and antibody to HIV. These samples were then tested individually (not by pooling) using the COBAS TaqScreen MPX (Roche Molecular Systems, Branchburg, New Jersey, USA) test on the s201 system (Roche Instrument Center, Rotkreuz, Switerland), a screening nucleic acid testing (NAT) for HBV, HCV and HIV. The lower limit of detection of this assay for $\mathrm{HBV}$ is $3.7 \mathrm{IU} / \mathrm{ml}$ with a $95 \% \mathrm{CI}$ of 3.3 to $4.4 \mathrm{IU} / \mathrm{ml}$. Initial positive samples were then quantified for the HBV DNA levels by a standardised commercial HBV DNA assay, Artus HBV RG test (OIAGEN, Hilden, Germany). When used with the OIAamp DSP Virus Kit (OIAGEN) for HBV DNA extraction, the Artus HBV RG test has a 95\% lower limit of detection of $3.8 \mathrm{IU} / \mathrm{ml}$, with a linear range of detection of between 1.1 and $>4 \times 10^{9} \mathrm{IU} / \mathrm{ml}$. Since the serum HBV DNA levels of occult HBV subjects were expected to be very low, in order to minimise the chance of false-positive or false-negative results, the Artus HBV test was performed three times on three separate occasions in all the samples which tested positive by NAT. Definite OHB was defined as two or more of the three runs of assays showing detectable HBV DNA levels. Further serological tests including antibody to $\mathrm{HBsAg}$ (anti-HBs), and total and immunoglobulin $M$ ( $\operatorname{Ig} M)$ antibodies to hepatitis $B$ core antigen (anti-HBc) using the Elecsys 2010 system (Roche Diagnostics, Mannheim, Germany) were performed.

In the second prospective stage (cohort 2) started in January 2006, subjects were recruited on site during blood donation. After obtaining written informed consent from the donors, $15 \mathrm{ml}$ of blood were taken for serological tests (see below). The donors were interviewed with a questionnaire which included the following information: (1) personal history of previous donations, HBV vaccination, known hepatitis B, C and other liver diseases, jaundice, alcohol intake ( $>20 \mathrm{~g} /$ day), diabetes mellitus, hypertension, long-term medication and intake of traditional Chinese medications; and (2) family history of hepatitis B carriage, liver cancer and other chronic liver diseases.

During the recruitment period from 1 January 2006 to 3 June 2008 , a total of 9990 blood donors were recruited. The sera were first tested by NAT using the s201 system mentioned above. NAT-positive samples were then tested for HBsAg to diagnose overt CHB. The remaining NAT-positive samples which were $\mathrm{HBs} A g$ negative were tested for $\mathrm{OHB}$. Definite $\mathrm{OHB}$ was defined by two out of three positive HBV DNA tests (Artus HBV RG test, OIAGEN) on samples negative for HBsAg with the same criteria as mentioned above. Tests for anti-HBs and anti-HBc (total and IgM) as described above were also performed.

Donors with $\mathrm{OHB}$ from cohort 2 were recalled. Liver biochemistry was performed after a second written informed consent. Liver biopsies were performed in subjects who consented. Liver tissues were assessed for histology which was graded according to the Ishak's criteria. ${ }^{8}$ Total intrahepatic HBV DNA and covalently closed circular (ccc) DNA were assayed by real-time PCR, as described in previous studies. ${ }^{9} 10$ Briefly, primers and FRET (fluorescence resonance energy transfer) probes directed against the HBV surface region were used for real-time PCR quantification of the total intrahepatic HBV DNA in the Rotorgene 3000 Real-time Multiplex System (Corbett Research, Australia). For cccDNA detection (lower limit of detection 0.002 copies/cell), the extracted liver DNA was first treated with Plasmid-safe DNase (Epicentre, Madison, Wisconsin, USA), followed by real-time PCR using primers spanning the incomplete region in the HBV relaxed circular genome. Human genomic DNA content in the liver DNA extract was measured by real-time PCR using the $\beta$-globulin primers and probes in the LightCycler Control DNA Kit (Roche Applied Science, Mannheim, Germany). HBsAg mutations at amino acid 145 (G145R) were determined by PCR sequencing, using primers spanning the HBV surface gene at nucleotides 426-600 (HBsAg amino acid residues 134-148). The HBV DNA was amplified by semi-nested PCR, using the sense primer HBV406s (both first and second rounds; 5 '-CTTCATCCTGCTGCTATGCCT-3') and antisense primer HBV608a (first round; 5'-AAAGCCCAGGATGATGGGAT-3') or HBV600a (second round; 5'-CCANGATGATGGGATGGGAATAC-3'). The 216 bp amplicons were then sequenced bi-directionally by the second round primers. HBV genotypes were determined by phylogenetic comparison of the same HBV DNA surface gene amplicons with HBV viral reference sequences in GenBank.

Both stages of the study were approved by the Institutional Review Board of the University of Hong Kong/Hospital Authority Hong Kong West Cluster.

\section{Statistical analysis}

The present study was descriptive in nature. We calculated the prevalence of $\mathrm{OHB}$ in the study populations. Continuous variables were expressed as the mean with SD and range. Comparisons of the demographic data between different groups of subjects were performed by Student $t$ tests for continuous variables and $\chi^{2}$ tests for categorical variables. Two-tailed $p$ values of $<0.05$ were considered to be statistically significant.

\section{RESULTS}

In cohort 1 with $3044 \mathrm{HBsAg-negative} \mathrm{donors} \mathrm{(1525} \mathrm{males,} 1519$ females), the mean age was 33.1 years (SD 10.6, range 16.0-62.3). NAT by the s201 system identified 12 positive samples $(0.4 \%)$. Four samples had detectable HBV DNA by the Artus HBV RG test (two had 2 out of 3 tests, two had 1 out of 2 tests (sample volume not adequate for the third run)). If the latter two cases were also regarded as having $\mathrm{OHB}$, the prevalence of $\mathrm{OHB}$ was $0.13 \%$ with a $95 \%$ CI of $0.036 \%$ to $0.336 \%$. The HBV DNA levels of these six runs were 1.10, 1.21, 1.70, 2.16, 2.47 and $19.40 \mathrm{IU} / \mathrm{ml}$. Of the 12 NAT-positive samples, 10 with adequate volume for further anti-HBc testing, six were positive for anti-HBc (all were negative for IgM anti-HBc) of which two had $\mathrm{OHB}$. 
For the prospective cohort 2, the demographics and the report of the questionnaires of the 9990 donors recruited are listed in table 1 .

Figure 1 shows the multistep approach by which the donors with $\mathrm{OHB}$ were identified. $\mathrm{OHB}$ was found in 11 donors with detectable HBV DNA (three in all 3 runs, eight in 2 out of 3 runs). The prevalence of occult HBV was $0.11 \%$ (95\% CI $0.055 \%$ to $0.197 \%)$. There were another four donor samples with detectable HBV DNA only in 1 out of 3 runs. They were regarded as suspected $\mathrm{OHB}$.

The demographics, serum viral markers and serum HBV DNA levels of the 11 confirmed occult HBV donors are listed in table 2. Of these, 10 donors had no family history of $\mathrm{CHB}$; one donor was not sure. All had no family history of hepatocellular carcinoma or cirrhosis. Nine had given previous blood donations. Only two were known to have had HBV vaccinations (six had not received HBV vaccinations; three were not sure). When compared with blood donors without hepatitis $\mathrm{B}(\mathrm{n}=9956)$ and donors with $\mathrm{CHB}$ $(\mathrm{n}=23), \mathrm{OHB}$ donors were significantly older than donors without hepatitis $B$ (mean age 39.9 years (SD 12.1; range 20.4-57) vs 31.5 years (SD 10; range $16-65.8$ ), respectively, $p=0.005$ ) and donors with CHB (mean age 25.6 years (SD 7.7; range 18.3-49.0), $\mathrm{p}=0.003$ ). There were no significant differences in the gender ratio between the three groups (all $\mathrm{p}>0.05$ ).

Ten of the 11 samples of these $\mathrm{OHB}$ donors were positive for total anti-HBc but all were negative for anti-HBc IgM, indicating that these donors were not in the window phase of acute hepatitis B infection, when subjects are positive for HBV DNA and have yet to develop circulatory antibodies to $\mathrm{HBsAg}$.

Nine donors agreed to undergo further liver biochemical tests and viral sequencing, and six consented to liver biopsies. All these $\mathrm{OHB}$ donors had normal liver biochemistry, extremely low serum and liver HBV DNA and nearly normal liver histology (table 2). The HBV surface regions of all nine donor samples were successfully sequenced. Three donors carried genotype B $\mathrm{HBV}$ and six carried genotype C HBV. All nine showed wild-type glycine at HBsAg amino acid 145, indicating the absence of G145R mutations (the vaccine escape mutants).

\section{DISCUSSION}

The present study documented a population prevalence of $\mathrm{OHB}$ of $0.13 \%$ and $0.11 \%$ from two large cohorts of blood donors in

Table 1 Demographics and report of questionnaires of the 9990 donors

\begin{tabular}{|c|c|}
\hline No. of subjects & 9990 \\
\hline $\mathrm{M}: \mathrm{F}(\%)$ & $5550: 4440(55.6: 44.4)$ \\
\hline Mean age, years (SD, range) & $31.5(10.1,16-65.8)$ \\
\hline \multicolumn{2}{|l|}{ Report of questionnaires } \\
\hline \multicolumn{2}{|l|}{ Past personal history } \\
\hline Previous blood donation (yes: no: not sure) & 7714: $2245: 31$ (77.2: 22.5: 0.3\%) \\
\hline HBV vaccination (yes: no: not sure) & 2657: 3502: 3831 (26.6: 35.1: $38.4^{\circ}$ \\
\hline HBV infection (yes: no: not sure) & 11: 9906: 73 (0.1: 99.2: 0.7\%) \\
\hline HCV infection (yes: no: not sure) & 0: 9924: 66 (0: 99.3: 0.7\%) \\
\hline Jaundice (yes: no: not sure) & 44: 9745: 201 (0.4: 97.5: 2\%) \\
\hline Significant alcohol intake (yes: no) & 205: 9785 (2.1: 97.9\%) \\
\hline Diabetes mellitus (yes: no: not sure) & 15: 9939: 36 (0.2: 99.5: 0.4\%) \\
\hline Hypertension (yes: no: not sure) & 29: 9940: 21 (0.3: 99.5: 0.2\%) \\
\hline Long-term medication (yes: no) & 117: 9873 (1.2: $98.8 \%)$ \\
\hline \multicolumn{2}{|l|}{ Family history } \\
\hline HBV infection (yes: no: not sure) & 727: 9039: 224 (7.3: 90.5: 2.2\%) \\
\hline Liver cancer (yes: no: not sure) & 179: 9639: 172 (1.8: 96.5: 1.7\%) \\
\hline Chronic liver disease (yes: no: not sure) & 372: $9377: 241$ (3.7: 93.9: 2.4\%) \\
\hline
\end{tabular}

F, female; HBV, hepatitis B virus; HCV, hepatitis C virus; $M$, male.

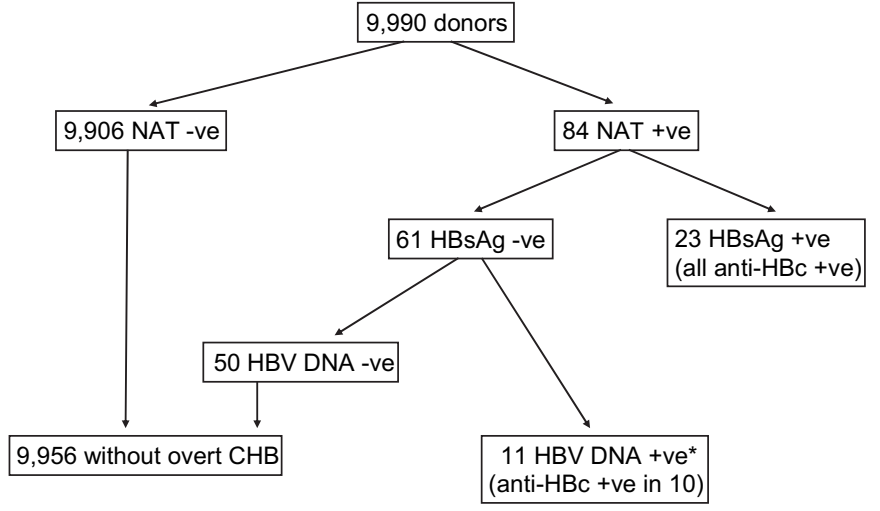

* Incidence of occult HBV: $0.11 \%$

Figure 1 Diagram showing the steps of tests to identify occult hepatitis $B$ donors (+ve, positive; -ve, negative).

Hong Kong, an endemic area for $\mathrm{CHB}$ with a prevalence rate of $8 \%$. These figures should be highly accurate. First, in contrast to some previous studies which adopted pooled sample testing with a pool of 6-500 donor sera, our study tested single samples individually. It has been shown that the sensitivity of identifying $\mathrm{OHB}$ is $3-10$ times lower in pool sample testing compared with individual single sample testing. ${ }^{11} 12$ Secondly, in order to reduce the chance of false-positive results due to contamination or real-time PCR noise signals as well as to enhance the detection rate of the PCR test in the context of extremely low HBV DNA levels, at least two out of three runs by Artus HBV RG test had to be positive before the samples were regarded as positive for OHB. Although it is sometimes difficult to distinguish between occult chronic HBV infection and acute infection in the window period, the fact that nearly all $\mathrm{OHB}$ samples were positive for anti-HBc (all in IgG form) suggested that the subjects did not have acute HBV infection during the window period when the blood was donated. A Taiwan study has also shown that all the identified HBV DNA-positive and HBsAgnegative follow-up samples had OHB with low HBV DNA titres and none was in the window period. ${ }^{13}$

Previous studies using in-house HBV DNA testing with a smaller number of subjects reported a rate of $0.01-0.02 \%$ and $2-4 \%$ for $\mathrm{OHB}$ in non-endemic and endemic areas of $\mathrm{CHB}$, respectively. ${ }^{4-16}$ The present study indicates that the prevalence of $\mathrm{OHB}$ was in fact low even in an area of high endemicity for HBV. This is in accordance with a recent Taiwan study showing a prevalence of $0.11 \%$ by using commercial NAT. ${ }^{13}$ NAT screening has been implemented in some countries in Europe, North America, Australia, Japan and southeast Asia. ${ }^{17-21}$ The results of the present study may provide important information for individual countries to consider whether universal NAT screening should be adopted. The implementation of NAT screening should also take into account the risk of transmission of $\mathrm{HBV}$ from $\mathrm{OHB}$ donor blood products to recipients which was not assessed in the present study. The estimated transmission rate of HBV from blood transfusion is 1 in 300000 in general. ${ }^{22} 23$ This rate should be even lower in an $\mathrm{OHB}$ population not suffering from acute $\mathrm{HBV}$ infection, although the exact chance of $\mathrm{HBV}$ transmission from $\mathrm{OHB}$ donors remains to be determined. There are a few case reports documenting possible $\mathrm{HBV}$ transmission from $\mathrm{OHB}$ donor blood products. ${ }^{24-26}$ A careful look-back study to determine the clinical outcome of recipients receiving blood products from occult HBV donors should be performed in the future. 
Table 2 Demographics, liver biochemistry, serum viral markers, serum HBV DNA levels, liver histology and intrahepatic HBV DNA levels of 11 occult HBV donors

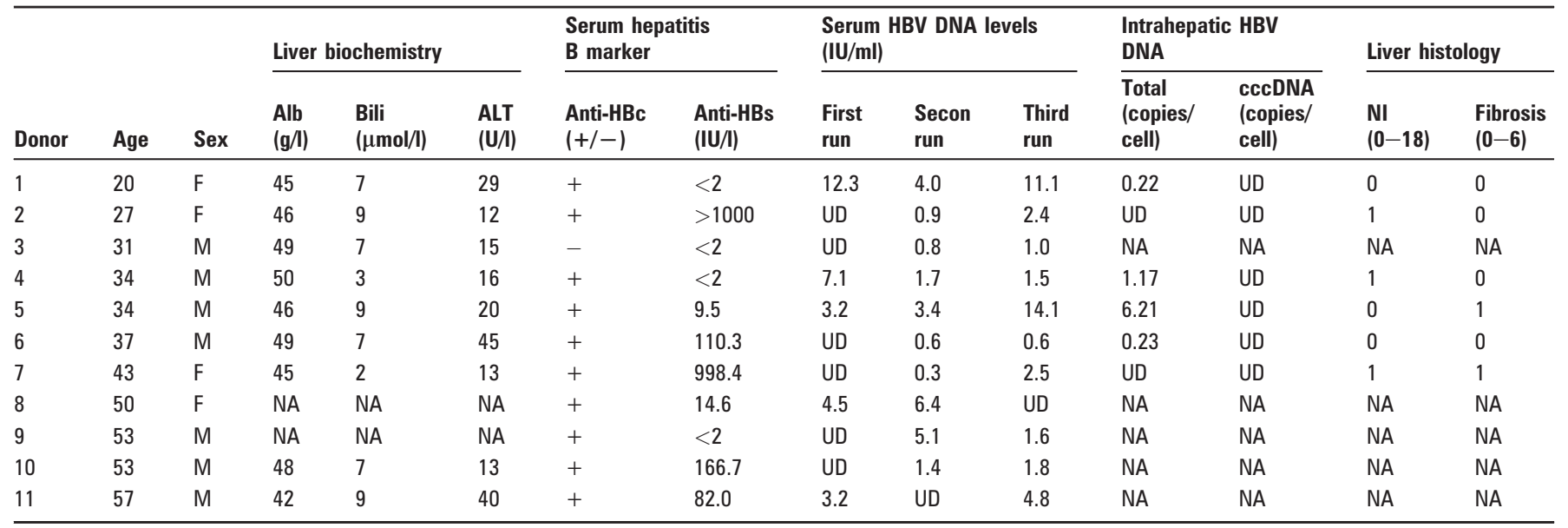

Alb, albumin (normal 38-48 g/l); ALT, alanine aminotransferase (normal $<53 \mathrm{IU} / \mathrm{I}$ for males, $<36 \mathrm{IU} / \mathrm{l}$ for females); Bili, bilirubin (normal $<19 \mu \mathrm{mol} / \mathrm{l}$ ); ccc, covalently closed circular; $\mathrm{F}$, female; $\mathrm{HBc}$, hepatitis B core; HBs, hepatitis B surface; HBV, hepatitis B virus; M, male; NA, not available; NI, necroinflammatory score; UD, undetectable.

We carried out the present study in two separate cohorts by using two different strategies of screening for $\mathrm{OHB}$. In the first cohort with 3044 donors, all the samples were first tested negative for HBsAg before being subjected to NAT and finally by sensitive HBV DNA assay. In the second prospective cohort with 9990 donors, the samples were first tested by NAT. NAT-positive samples were then tested for HBsAg. For NAT-positive and HBsAg-negative samples, HBV DNA assay was performed to identify $\mathrm{OHB}$. Both strategies yield very similar prevalence rates. This suggests that initial screening by HBsAg followed by NAT has the same yield of detection as with initial screening by NAT. HBsAg testing followed by NAT is obviously cheaper. However, a practical advantage of adopting the second strategy of initial screening by NAT is that there will be a faster release of blood products for use once the NAT is negative since the sensitivity of NAT is superior to detection of HBsAg by enzyme immunoassay (EIA). ${ }^{27}$ Another potential advantage of using initial NAT screening is its ability to detect HBV in the presence of antigenically modified HBsAg such as G145R mutants, which may give rise to negative results in $\mathrm{HBsAg}$ detection assays. ${ }^{28}$ However, our study revealed that none of the occult HBV carried this G145R mutation, a finding consistent with other studies. ${ }^{29} 30$

Since the cost for universal NAT screening is high, anti-HBc screening has been suggested as an alternative. The positivity rate of isolated anti-HBc in the general population directly correlates with the endemicity of $\mathrm{CHB}$. It is estimated to be up to $17 \%$ in areas of intermediate endemicity. ${ }^{31}$ In areas which are highly endemic for HBV infection, such as Hong Kong, the prevalence rate of anti-HBs positivity was as high as $40 \%$ before the implementation of universal HBV vaccination. ${ }^{32}$ A majority of these anti-HBs-positive subjects would also be positive for anti-HBc. In light of the low prevalence rate of $\mathrm{OHB}$ observed in the present study, a high proportion of blood donations may be discarded from usage unnecessarily if isolated anti-HBc positivity is used for screening HBV.

In the $11 \mathrm{OHB}$ donors identified in cohort 2, all had normal liver biochemistry and nearly normal liver histology with no or insignificant necroinflammation and fibrosis. Performing liver biopsies on these subjects was to be more confirmatory of the diagnosis of $\mathrm{OHB}$ as we could not completely rule out falsepositive HBV DNA results obtained by very sensitive assay. In addition, there are no data on the possible liver injury and intrahepatic virological status in these subjects. The serum HBV DNA levels were very low, with the highest value of $14.1 \mathrm{IU} / \mathrm{ml}$
(19.4 IU/ml in cohort 1). This is consistent with the very low or undetectable total intrahepatic HBV DNA, indicating that HBV inside the liver is replicating at an extremely low rate. It has been shown that most patients with $\mathrm{CHB}$ with $\mathrm{HBsAg}$ seroclearance still have detectable total intrahepatic and cccDNA. ${ }^{93}$ In the present study, the undetectable cccDNA in the liver tissues is likely to be related to the extremely low viral load. This suggests a favourable long-term prognosis in donors with $\mathrm{OHB}$. However, there are still two main concerns for these $\mathrm{OHB}$ donors despite the low level of viral replication. There is a possibility of reactivation of the hepatitis $B$ disease if these $\mathrm{OHB}$ donors should require immunosuppressive therapy in the future, especially in regimens containing rituximab. ${ }^{34}$ Also the low viral load is still of a theoretical concern in transmitting $\mathrm{HBV}$. It has been shown that as few as 1-10 HBV particles can infect chimpanzees. ${ }^{35}$

One limitation of the present study was that the prevalence of $\mathrm{OHB}$ elucidated by the present study may not be totally representative for the general population in Hong Kong since it recruited blood donors who were relatively young (mean age of 31.5 years, table 1) and healthy.

In conclusion, with the prevalence of only $0.1 \%$ of the population having $\mathrm{OHB}$ in an endemic area of high $\mathrm{HBV}$ prevalence, the impact on the transfusion services is expected to be low. Implementation of universal screening of $\mathrm{OHB}$ in blood transfusion services should be determined with the consideration of both the disease prevalence and the cost incurred by the programme.

Acknowledgements The authors are indebted to Elizabeth Kin-Ming Chua, Vincent Wing-Shun Ngai, Connie Wai-Fan Ng, Maggie Shuk-Ying Wong, Mario Man-Lit Tang, Jeannie Yi-Lam Cheung, Cookie Wing-Wa Tang and all the involved staff in the Red Cross Blood Transfusion Centers for their assistance in conducting the study.

Competing interests None.

Ethics approval This study was conducted with the approval of the Institutional Review Board of the University of Hong Kong/Hospital Authority Hong Kong.

Provenance and peer review Not commissioned; externally peer reviewed.

\section{REFERENCES}

1. Yuen MF, Lai CL. Treatment of chronic hepatitis B. Lancet Infect Dis 2001:1:232-41.

2. Allain JP. Occult hepatitis B virus infection. Transfus Clin Biol 2004;11:18-25.

3. Raimondo G, Allain JP, Brunetto MR, et al. Statements from the Taormina expert meeting on occult hepatitis B virus infection. J Hepatol 2008;49:652-7.

4. Reesink HW, Engelfriet CP, Henn G, et al. Occult hepatitis B infection in blood donors. Vox Sang 2008;94:153-66. 
5. Georgiadou SP, Zachou K, Rigopoulou E, et al. Occult hepatitis B virus infection in Greek patients with chronic hepatitis $C$ and in patients with diverse nonviral hepatic diseases. J Viral Hepat 2004;11:358-65.

6. Song EY, Yun YM, Park MH, et al. Prevalence of occult hepatitis B virus infection in a general adult population in Korea. Intervirology 2009;52:57-62.

7. Bhatti FA, Ullah Z, Salamat N, et al. Anti-hepatitis B core antigen testing, vira markers, and occult hepatitis B virus infection in Pakistani blood donors: implications for transfusion practice. Transfusion 2007:47:74-9.

8. Ishak K, Baptista A, Bianchi L, et al. Histological grading and staging of chronic hepatitis B. J Hepatol 1995;22:696-9.

9. Yuen MF, Wong DK, Fung J, et al. HBsAg seroclearance in chronic hepatitis B in Asian patients: replicative level and risk of hepatocellular carcinoma.

Gastroenterology 2008;135:1192-9.

10. Werle-Lapostolle B, Bowden S, Locarnini S, et al. Persistence of cccDNA during the natural history of chronic hepatitis B and decline during adefovir dipivoxil therapy. Gastroenterology 2004;126:1750-8.

11. Kleinman SH, Strong DM, Tegtmeier GG, et al. Hepatitis B virus (HBV) DNA screening of blood donations in minipools with the COBAS AmpliScreen HBV test. Transfusion 2005; 45:1247-57.

12. Owusu-Ofori S, Temple J, Sarkodie F, et al. Predonation screening of blood donors with rapid tests: implementation and efficacy of a novel approach to blood safety in resource-poor settings. Transfusion 2005;45:133-40.

13. Li L, Chen PJ, Chen MH, et al. A pilot study for screening blood donors in Taiwan by nucleic acid amplification technology: detecting occult hepatitis B virus infections and closing the serologic window period for hepatitis C virus. Transfusion 2008;48:1198-206.

14. Luo KX, Zhou R, He C, et al. Hepatitis B virus DNA in sera of virus carriers positive exclusively for antibodies to the hepatitis B core antigen. J Med Virol 1991;35:55-9.

15. Shih LN, Sheu JC, Wang JT, et al. Serum hepatitis B virus DNA in healthy HBsAg-negative Chinese adults evaluated by polymerase chain reaction. J Med Virol 1990;32:257-60

16. Wang JT, Wang TH, Sheu JC, et al. Detection of hepatitis B virus DNA by polymerase chain reaction in plasma of volunteer blood donors negative for hepatitis B surface antigen. J Infect Dis 1991;163:397-9.

17. Coste J, Reesink HW, Engelfriet CP, et al. Implementation of donor screening for infectious agents transmitted by blood by nucleic acid technology: update to 2003 Vox Sang 2005;88:289-303.

18. Stramer SL, Caglioti S, Strong DM. NAT of the United States and Canadian blood supply. Transfusion 2000;40:1165-8.

19. Velati C, Fomiatti L, Baruffi L, et al. Impact of nucleic acid amplification technology (NAT) in Italy in the three years following implementation (2001-2003). Euro Surveill 2005:10:12-14
20. Seed CR, Cheng A, Ismay SL, et al. Assessing the accuracy of three viral risk models in predicting the outcome of implementing HIV and HCV NAT donor screening in Australia and the implications for future HBV NAT. Transfusion 2002:42:1365-72.

21. Murokawa H, Yoshikawa A, Ohnuma H, et al. Epidemiology of blood donors in Japan, positive for hepatitis $\mathrm{B}$ virus and hepatitis $\mathrm{C}$ virus by nucleic acid amplification testing. Vox Sang 2005:88:10-16.

22. Laperche S. Blood safety and nucleic acid testing in Europe. Euro Surveill 2005; 10:3-4.

23. Stramer SL. US NAT yield: where are we after 2 years? Transfus Med 2002;12:243-53

24. Baginski I, Chemin I, Hantz O, et al. Transmission of serologically silent hepatitis $\mathrm{B}$ virus along with hepatitis $\mathrm{C}$ virus in two cases of posttransfusion hepatitis. Transfusion 1992; 32:215-20

25. Thiers V, Lunel F, Valla D, et al. Post-transfusional anti-HCV-negative non-A non-B hepatitis (II) serological and polymerase chain reaction analysis for hepatitis $C$ and hepatitis B viruses. J Hepatol 1993; 18:34-9.

26. Hoofnagle $\mathbf{J H}$, Seeff LB, Bales ZB, et al. Type B hepatitis after transfusion with blood containing antibody to hepatitis B core antigen. N Engl J Med 1978;298:1379-83.

27. Biswas R, Tabor E, Hsia CC, et al. Comparative sensitivity of HBV NATs and HBsAg assays for detection of acute HBV infection. Transfusion 2003:43:788-98.

28. La'ulu SL, Roberts WL. The analytic sensitivity and mutant detection capability of six hepatitis B surface antigen assays. Am J Clin Pathol 2006;125:748-51.

29. Jeantet $\mathbf{D}$, Chemin I, Mandrand B, et al. Cloning and expression of surface antigen from occult chronic hepatitis $B$ virus infections and their recognition by commercial detection assays. J Med Virol 2004;73:508-15.

30. Cacciola I, Pollicino T, Squadrito G, et al. Occult hepatitis B virus infection in patients with chronic hepatitis C liver disease. N Engl J Med 1999;341:22-6.

31. Bréchot C, Thiers V, Kremsdorf D, et al. Persistent hepatitis B virus infection in subjects without hepatitis B surface antigen: clinically significant or purely 'occult'? Hepatology 2001;34:194-203.

32. Yeoh EK, Chang WK, Kwan JPW. Epidemiology of viral hepatitis B infection in Hong Kong. In: Lam SK, Lai CL, Yeoh EK, eds. Viral hepatitis B infection in the Western Pacific region: vaccine and control. Singapore: World Scientific, 1984:33-41.

33. Yuen MF, Wong DK, Sablon E, et al. HBsAg seroclearance in chronic hepatitis B in the Chinese: virological, histological, and clinical aspects. Hepatology 2004;39:1694-701.

34. Tsutsumi Y, Kanamori H, Mori A, et al. Reactivation of hepatitis B virus with rituximab. Expert Opin Drug Saf 2005;4:599-608.

35. Tabor E, Purcell RH, Gerety RJ. Primate animal models and titered inocula for the study of human hepatitis A, hepatitis B, and non-A, non-B hepatitis. J Med Primatol 1983;12:305-18

\section{Editor's quiz: GI snapshot}

\section{An unusual inflammation of the colon}

A 27-year Caucasian man received an unrelated donor bone marrow transplant for severe aplastic anaemia. Six weeks later he was re-admitted to hospital with a febrile illness. He developed profuse non-bloody diarrhoea and cervical lymphadenopathy was detected. Blood tests showed pancytopenia and peak

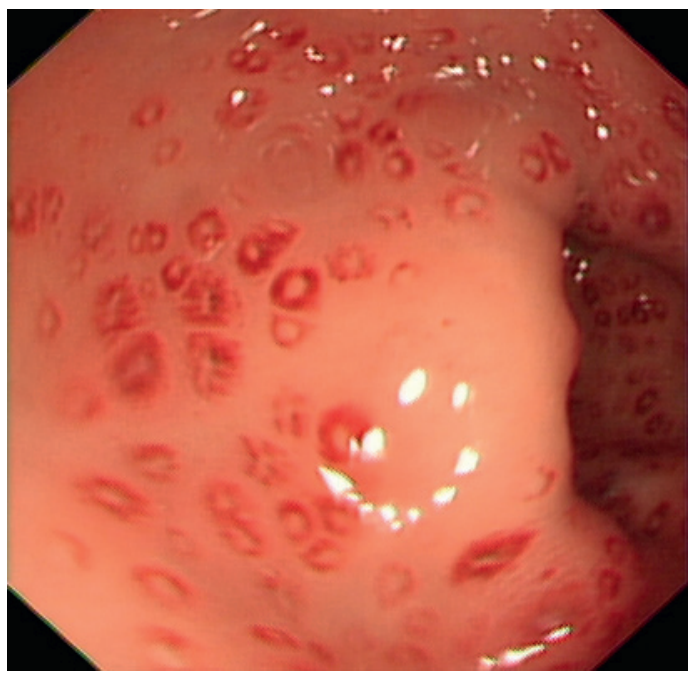

Figure 1 Endoscopic view of the rectal mucosa. concentrations of C-reactive protein $100 \mathrm{mg} / \mathrm{l}$, alanine aminotranferase $357 \mathrm{U} / 1$ and alkaline phosphatase $197 \mathrm{U} / 1$. Standard stool microscopy and culture did not reveal any abnormalities and tests for Clostridium difficile toxins $\mathrm{a}$ and $\mathrm{b}$ were negative. Flexible sigmoidoscopy revealed the following appearances from the rectum to the extent of the examination (figure 1).

\section{QUESTION}

What is the cause for this atypical colitis and how would you treat it?

See page 1427 for the answer

\section{P Selinger, ${ }^{1}$ G Howarth, ${ }^{2}$ R P Willert}

${ }^{1}$ Department of Gastroenterology, Manchester Royal Infirmary, Central Manchester University Hospitals NHS Foundation Trust, Manchester, UK; ${ }^{2}$ Department of Pathology, Manchester Royal Infirmary, Central Manchester University Hospitals NHS Foundation Trust, Manchester, UK

Correspondence to Dr Christian Selinger, Department of Gastroenterology, Manchester Royal Infirmary, Central Manchester University Hospitals NHS Foundation Trust, Oxford Road, Manchester M13 9WL, UK; christian.selinger@web.de

\section{Competing interests None.}

Patient consent Obtained

Provenance and peer review Not commissioned; externally peer reviewed.

Published Online First 10 June 2010

Gut 2010;59:1393. doi:10.1136/gut.2010.209742 


\section{GUT}

\section{Prevalence of occult hepatitis B infection in a highly endemic area for chronic hepatitis B: a study of a large blood donor population}

Man-Fung Yuen, Cheuk-Kwong Lee, Danny Ka-Ho Wong, et al.

Gut 2010 59: 1389-1393 originally published online July 30, 2010

doi: $10.1136 /$ gut.2010.209148

Updated information and services can be found at:

http://gut.bmj.com/content/59/10/1389.full.html

These include:

References This article cites 34 articles, 2 of which can be accessed free at: http://gut.bmj.com/content/59/10/1389.full.html\#ref-list-1

Article cited in:

http://gut.bmj.com/content/59/10/1389.full.html\#related-urls

Email alerting Receive free email alerts when new articles cite this article. Sign up in service the box at the top right corner of the online article.

Notes

To request permissions go to:

http://group.bmj.com/group/rights-licensing/permissions

To order reprints go to:

http://journals.bmj.com/cgi/reprintform

To subscribe to BMJ go to:

http://group.bmj.com/subscribe/ 